\title{
Glacier changes in the Austrian Alps during the last three decades, derived from the new Austrian glacier inventory
}

\author{
A. LAMBRECHT, M. KUHN \\ Institute of Meteorology and Geophysics, University of Innsbruck, Innrain 52, A-6020 Innsbruck, Austria \\ E-mail: astrid.lambrecht@uibk.ac.at
}

\begin{abstract}
Beginning in 1996, aerial photographs were taken for a new Austrian glacier inventory, resulting in digital elevation models (DEMs) and digital orthoimages. An earlier inventory of the Austrian glaciers containing the original aerial photographs and glacier maps and a manual evaluation of various glacier parameters as of $\mathbf{1 9 6 9}$ has been re-evaluated at the present state of the art. The two inventories provide the basis for the comparison of glacier reactions over a period of 29 years. In general a reduction of glacier area is observed for almost all Austrian glaciers between 1969 and 1998. The overall reduction in ice-covered area is $17 \%$. The glacier volume change calculated from the DEMs amounts to about $5 \mathrm{~km}^{3}$. This is almost $22 \%$ of the ice volume in Austria in 1969, estimated from a volume-area relation. Changes of individual glaciers, however, show a wide variability, depending on their size and physiographic setting.
\end{abstract}

\section{INTRODUCTION}

During recent decades, glaciers in the Alps were in a state of strong retreat. A previous phase of partial advance, as a reaction to the cool years during the second half of the 1970s, terminated in the mid-1980s (Patzelt, 1993). Since then almost all glaciers, at least in Austria, show a continuous reduction in area. A quantitative analysis of ice loss and the change in glacierized area in Austria so far was only made for very few glaciers that were subject to massbalance and surveying projects.

There is general agreement that glaciers play an important role in the hydrological system of the Alps, storing water during cold and wet periods and releasing water in hot and dry phases. The sea-level equivalent of alpine glaciers worldwide is small ( $\sim 0.24 \mathrm{~m}$; Church and others, 2001), but the relative contribution to global sea-level rise during the next 100 years is expected to be significant (Church and others, 2001; Dyurgerov, 2003). In order to quantify glacier changes for larger regions, it is very useful to collect the required information in inventories. Such inventories also allow a statistical analysis of ice-covered areas in terms of glacier size, elevation distribution, exposition and other properties.

A first inventory for the glaciers of Austria was compiled for the reference year 1969 at the University of Innsbruck (Patzelt, 1978, 1980; Groß, 1987). For that purpose, all Austrian glaciers were covered by aerial photographs, which were then used for the photogrammetric production of glacier maps. The maps contain elevation contours, spot heights, glacier boundaries and snowlines on a scale of $1: 10000$ and $1: 5000$. In addition to the maps, areaelevation distributions were calculated for the individual glaciers and information was collected on former glacier stands. One overall result of this study is a total glacier area of $540 \pm 10 \mathrm{~km}^{2}$ for 925 glaciers in 1969 .

The observed change of the glaciers in the Austrian Alps from the 1960s until the mid-1990s was one motivation for the initiation of a new glacier inventory in 1996. Similar activities were also started in other countries during this period. In Switzerland, for example, a new inventory was based on satellite imagery, mainly using Landsat Thematic
Mapper scenes analyzed by semi-automatic methods (Paul and others, 2002). For Austria the aerial photographic surveys took place from 1996 to 2002, where most of the glaciers were covered in 1997 and 1998. In a pilot study, the feasibility of digital photogrammetric methods has been tested (Würländer and Eder, 1998; Eder and Würländer, 2000) and the subsequent analysis was done on a digital basis. Contour maps on a scale of 1:10000, digital elevation models (DEMs) and orthoimages were produced. A number of topographic parameters and characteristic values were then derived from the digital products, as described below. All these data are now available through a geographical information system (GIS) for glaciological and hydrological interpretation. Here we focus on glacier changes between the two existing inventories and their relation to regional and local conditions.

\section{DATA ACQUISITION AND DATA PROCESSING}

For the new inventory, survey flights were carried out by the Division of Aerial Reconnaissance of the Austrian Army between 1996 and 1998 in order to capture aerial photographs of all Austrian glaciers (Fig. 1). Additional image flights by other projects were also used for photogrammetric data acquisition of missing regions. Because of the requirement of cloud-free and snow-free scenes, it took several years (1996-2002) to complete all surveys. Most glaciers ( $73 \%$ by number and $81 \%$ by area), however, could be covered in the years 1997 and 1998. The image scale varies from $1: 15000$ to $1: 35000$ and photographs were taken partly in colour and partly in black and white. Basic information for the photogrammetric data acquisition, like control points or an existing DEM of the alpine region, was delivered by the Federal Office of Metrology and Surveying (BEV) in Vienna.

\section{Basic preparation and DEM generation}

During the establishment of the new Austrian glacier inventory, a new approach for semi-automatic DEM generation from aerial photographs was developed (Würländer and Eder, 1998). With this method it was possible to 


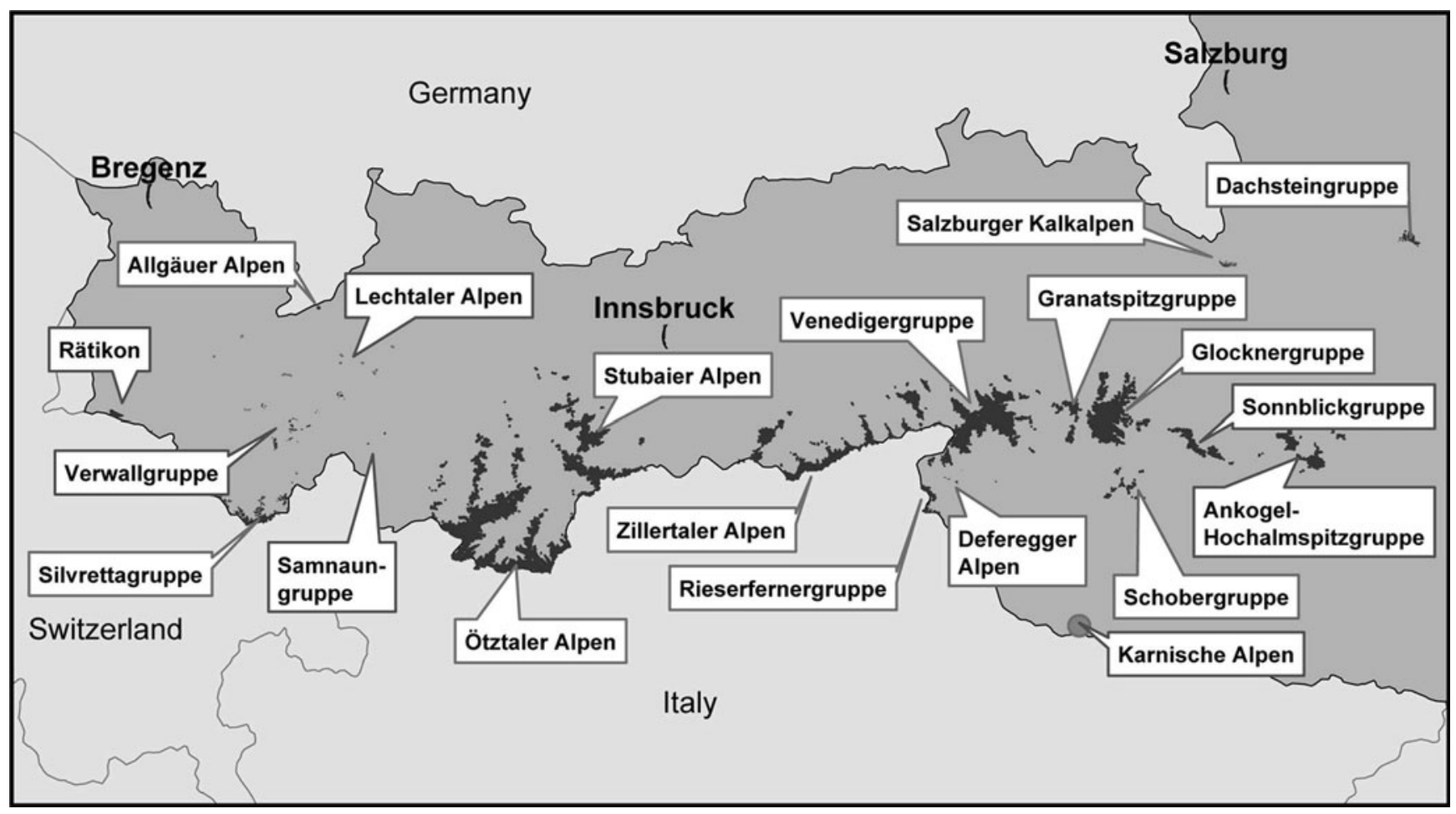

Fig. 1. Map of the ice-covered areas in Austria, including the names of the mountain ranges.

derive good-quality DEMs with a minimum effort for manual verification and editing. The required mean vertical accuracy of $\pm 1.9 \mathrm{~m}$ for the elevation model allowed a semiautomatic DEM generation (Würländer and Eder, 1998).

The production line is based on the photogrammetric software package of Inpho, a German photogrammetry company. Image orientation is computed by automatic aerial triangulation, while the required control points and the relevant areas and objects are identified at the analytical analyzer Zeiss Planicomp P2. Thereafter the DEM is calculated automatically on a $20 \mathrm{~m}$ raster. Quality control is achieved by verification of independent control points, and, if necessary, DEM editing, within the relevant areas. For the high-resolution calculation, gaps and boundary areas are filled with elevation information provided by the BEV. Next, the final DEM derivation on a $10 \mathrm{~m}$ raster, including identified objects, and the subsequent calculation of the orthoimage (resolution of $0.5 \mathrm{~m}$ ), are carried out. Image mosaics for larger areas are then produced with the ERDAS software.

In a pilot study (Würländer and Eder, 1998; Eder and others, 2000) an efficient work flow was developed, integrating the different processing steps, especially for the creation of the glacier inventory. The DEM can be considered as the central part, which serves as the base for all change calculations.

\section{Detection of glacier boundaries}

First of all, a clear definition of the term glacier area is required in order to be consistent throughout the entire analysis. According to the definitions of the 1969 inventory, glaciers are mapped under hydrological aspects dividing individual glaciers at the drainage boundaries. Snow and firn areas adjoining the glacier are included in the glacier area, because in most cases it is not possible to decide if these areas cover ice or rock. For the identification of debris- covered parts of the glaciers, the surface shape and roughness of the DEM, as well as existing photographs, were used. Following these guidelines assured the comparability with results from the 1969 inventory. The final identification of the glacier boundaries was done manually using the stereo model and the corresponding orthoimages. The identified glacier boundaries were imported into a GIS, including additional information like drainage area, identification number, glacier name, glacier area, aspect of the ablation area, the accumulation area, etc. Once the DEMs and the glacier boundaries existed, 'derived' products could be calculated: masks for individual glaciers, area-elevation distributions, minimum, maximum and mean elevation of the glaciers.

\section{COMPARISON WITH THE 1969 INVENTORY}

Data from the 1969 inventory only existed as analogue maps and tables. To enable a direct comparison and the quantification of changes, it was necessary to digitize the 1969 inventory. All glacier boundaries were digitized from the scanned maps and compared to the tabulated values. It is important to note that the total glacier area of $540 \mathrm{~km}^{2}$ from the old inventory (Patzelt, 1978) does not include the firn areas above the bergschrund. The delineation of glacier boundaries in both of the new inventories, however, also includes these firn areas as recommended by UNESCO (1970). All comparisons were made on the basis of this latter glacier area definition.

\section{Re-analysis and import}

In a pilot study, the comparability of the two inventories was tested. For this purpose a test site was chosen in the Zillertal, and certain minimum requirements on the old map material were defined: elevation contours should have a maximum spacing of $20 \mathrm{~m}$, the map scale should be at least 1:10000 
Table 1. Ice-covered mountain regions, the availability of DEMs and the analysis status of the 1969 inventory

\begin{tabular}{|c|c|c|}
\hline Mountain area & DEM in year & Photogrammetric analysis, 1969 \\
\hline Allgäuer Alpen & 2000 & \\
\hline Ankogel-Hochalmspitzgruppe & 1969, 1998 & New \\
\hline Dachsteingruppe & 1969, 2002 & Digitized \\
\hline Deferegger Alpen & 1998 & Only table values \\
\hline Glocknergruppe & 1969, 1998 & Digitized \\
\hline Karnische Alpen & 1997, Dipl. Ing. Zistler & Only table values \\
\hline Lechtaler Alpen & 1996 & Only table values \\
\hline Ötztaler Alpen & 1969, 1997 & Digitized \\
\hline Rätikon & 1969,1996 & New \\
\hline Rieserfernergruppe & 1998 & Only table values \\
\hline Salzburger Kalkalpen & 1969, 2002 & Digitized \\
\hline Samnaungruppe & 2002 & Only table values \\
\hline Schobergruppe & 1998 & Only table values \\
\hline Sonnblickgruppe & 1969, 1998 & Digitized \\
\hline Stubaier Alpen & 1969,1997 & New \\
\hline Venedigergruppe & 1969,1998 & New \\
\hline Verwallgruppe & 2002 & Only table values \\
\hline Zillertaler Alpen & 1969, 1999 & Only table values \\
\hline
\end{tabular}

and a coordinate grid for co-referencing should be included (Würländer and Eder, 1998). Only a part of the old maps fulfilled all requirements. Thus, the original aerial photographs from several regions (Table 1) were analyzed according to the method described above. For all other regions, elevation contours and glacier boundaries were digitized from the projected scans, which were co-registered by grid matching. During the subsequent DEM generation, known problems, such as non-uniform density of elevation information and terrace effects, were accounted for. The resulting elevation models were tested by calculating intermediate elevation contours. Using additional geomorphological data and the stepwise reduced contour intervals, the final DEM was calculated (Würländer and Eder, 1998) and imported into the inventory GIS.

For some minor areas, neither maps, nor aerial photographs from 1969 existed (about 3\% of the total glacier area of 1969). Without the respective elevation models and digital glacier boundaries, the aerial changes could only be derived from the tabular values of 1969. It was not possible to calculate volume differences for these areas.

\section{Calculation of differences}

The calculation of temporal glacier changes requires careful methods. In the pilot study for the glacier inventory, a program was developed for the production of glaciological difference products according to an approach by Finsterwalder (1953). The bases for these calculations are planimetric glacier areas which are used to derive differences in area, mean elevations and volume within predefined elevation bands. The standard methods provided by modern GIS do not provide the same accuracy for the simultaneous evaluation of both changing volume and changing area within individual elevation bands. The use of DEMs allows a more efficient production of results compared to former semi-automatic delineation of elevation contours (Reinhardt and Rentsch, 1986; Rentsch and others, 1990). A number of secondary products, such as maps of slope and aspect, are readily produced from the DEM. The program used for the further processing is based on raster calculations (Würländer and others, 1999; Würländer and Kuhn, 2000). The DEMs of the glaciers are resampled on a $5 \mathrm{~m}$ raster, and glacier masks are generated on the same raster resolution for both observation times. The basis for calculating the differences in volume is the common outer glacier boundary. Differences in mean elevations are calculated on the basis of the common inner glacier boundary. Elevation differences for gridpoints which are classified within different elevation bands for the two dates are added to the different elevation bands according to an assumed linear change of elevation.

The program calculates the area-elevation distribution within variable elevation bands on the basis of the glacier masks and the DEMs for both dates. Also differences in area and volume, the mean elevation within each elevation band, a raster of elevation differences, the mean elevation of the glacier and the highest and lowest points of the glacier are provided. All glaciers contained in the inventory have been processed with this program. The essential output was then imported into the specially designed GIS for further calculations.

\section{TEMPORAL HOMOGENIZATION OF THE INVENTORY}

Aerial photography for the recent inventory was spread over the years 1996-2002. For the investigation of changes over a fixed time period for all glaciers, a simple degree-day approach was used to interpolate the data to a common year, which was chosen to be 1998 . Although only $38.5 \%$ of the total glacier area in Austria was covered in 1998, this is the year where only $7 \%$ of the glacier area needs to be interpolated over a period of 2 years or more. Most glaciers were covered by aerial photography during the survey in 1997 (43.5\%), and 10.8\% have to be interpolated from 1999 to 1998 . With this approach the introduced error will be minimized. 


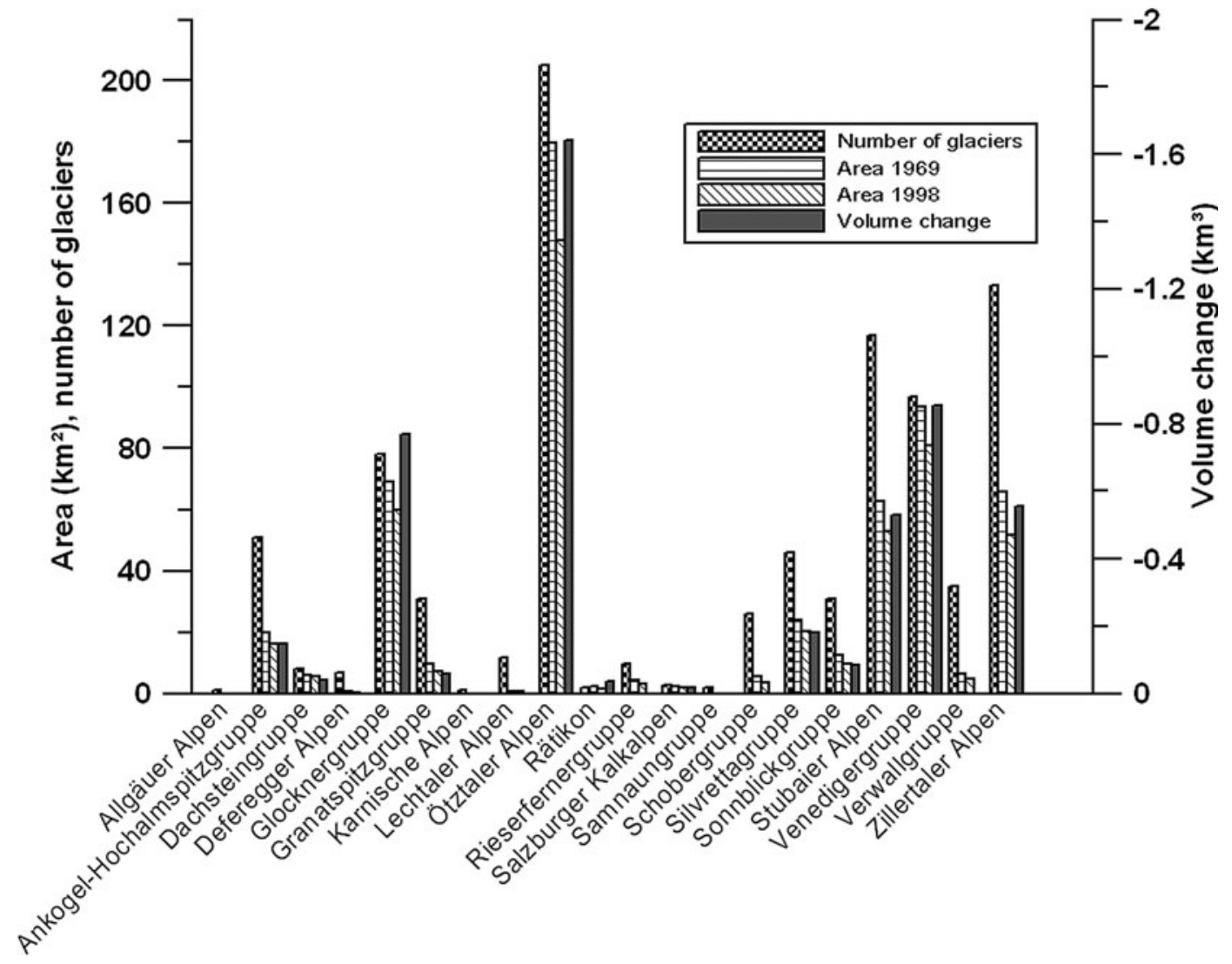

Fig. 2. Number of glaciers, ice-covered area in 1969 and 1998 and glacier volume loss in the different mountain regions in the Austrian Alps.

For several glaciers in the Ötztal, which itself represents $74 \%$ of the glacier survey of 1997 , there exist long-term mass-balance series (Hintereisferner, Vernagtferner and Kesselwandferner), as well as temperature data from nearby Vent station. This makes it possible to test the simple degreeday model in a region which represents a considerable part of the glacier area to be interpolated.

In order to recalculate the data to a common year, the daily mean temperatures of Vent station (1900 m a.s.l., about $10 \mathrm{~km}$ from Hintereisferner) were used. For all years since 1969, daily mean temperatures were calculated from the Vent data within the $50 \mathrm{~m}$ elevation bands using a lapse rate of $0.6^{\circ} \mathrm{C}(100 \mathrm{~m})^{-1}$. Then the degree-day sums were determined within the individual elevation bands. An analysis of glacier area variations in the Stubaital, based on remotesensing data, indicates that there was no significant change in glacier size between 1969 and 1985 (Schicker, 2006). Therefore it is assumed for this analysis that the observed changes occurred between 1985 and the recent surveys in a continuous way.

In the case of the Ötztal glaciers a mean value of the degree-day sums was determined for all years between 1985 and 1997:

$$
\overline{\mathrm{DDS}}=\frac{\sum_{i=1985}^{1997} \mathrm{DDS}_{i}}{(1997-1985+1)}
$$

where $\overline{\mathrm{DDS}}$ is the mean degree-day sum for all years and $\mathrm{DDS}_{i}$ is the degree-day sum for the year $i$. The observed mean annual area change

$$
\overline{\Delta A}=\frac{\sum_{i=1985}^{1997} \Delta A_{i}}{(1997-1985+1)}=A_{1997}-A_{1969}
$$

during this period was then weighted by the ratio of the mean annual degree-day sum and the degree-day sum for 1998 and the result added to the glacier area of 1997:

$$
A_{1998}=A_{1997}+\overline{\Delta A}\left(\frac{\mathrm{DDS}_{1998}}{\overline{\mathrm{DDS}}}\right) .
$$

This was done in an analogue way also for the other areas, depending on the year of the survey, and similar calculations were carried out to determine volume changes for the standard year 1998. With this method, interannual variations of the climatic conditions are taken into account, resulting in larger changes if the interpolated time-span was warmer than the mean temperature of the entire period, and conversely. For volume changes, this method will even work for individual glaciers due to the strong correlation between positive temperatures and glacier melt rates (Lang, 1968; Hoinkes and Steinacker, 1975). Glacier area changes also depend strongly on ice-thickness distribution and massbalance history, which makes it difficult to predict area changes from climate data alone. For a whole glacier region, individual anomalies will be compensated, however, and the method applied here will provide better results than a purely linear interpolation.

In order to estimate the error range, the regions Ötztal and Stubaital (total glacier area of $205 \mathrm{~km}^{2}$ ) were interpolated from the year of the survey, 1997, to 1998 using factors of 1 (linear extrapolation) and 2 (doubled effect compared to the mean trend over the entire period) as maximum bounds, compared to the determined factor of 1.3. The difference in the resulting total area is only $1.5 \%$ for the two limiting values, indicating a maximum error of the same order. For glacier volumes, only the variation of volume change could be estimated, yielding a maximum 
value of $5.3 \%$ (corresponding to $0.12 \mathrm{~km}^{3}$ ) with the same bounds. The related variation in surface height is $0.6 \mathrm{~m}$, which is still lower than the accuracy of the elevation model itself.

This consideration demonstrates that the applied method results in realistic glacier area and ice-volume changes for the standardized year 1998, where the errors from the interpolation are within the bounds of the inventory errors.

Because most of the regions were interpolated only over 1 year, changes in the results are rather small. The standardized glacier area in 1998 was $469.7 \mathrm{~km}^{2}$ (total glacier area summarized from the different dates: $470.9 \mathrm{~km}^{2}$ ) and the area reduction since 1969 was $17.1 \%$. The difference in glacier volume for the common year 1998 is $-4.92 \mathrm{~km}^{3}$ (compared to $4.82 \mathrm{~km}^{3}$ for the initial inventory state). This means a change in area of $-0.24 \%$ and a change in volume of $2.07 \%$ compared to the initial inventory results.

\section{GLACIER CHANGES OVER THREE DECADES}

\section{Changes in glacier area}

The analysis of the two inventories shows a reduction in glacier area of $17.1 \%$, from $567 \mathrm{~km}^{2}$ to $471 \mathrm{~km}^{2}$, for the Austrian Alps during the three decades. Figure 2 shows the area distribution in 1969 and 1998 for the individual glacierized mountain regions. In 7 out of 20 regions, the total glacier area is still more than $10 \mathrm{~km}^{2}$. The largest icecovered region is the Ötztaler Alpen with a glacier area of $148 \mathrm{~km}^{2}$. For this region, the area change of $-17.6 \%$ is slightly higher than the mean value.

In general, regions with extensive glacier cover show area changes that are close to the mean value. In contrast, regions with only minor glaciation show rather variable changes: glaciers in the Karnische Alpen (total area $0.18 \mathrm{~km}^{2}$ ) increased in area by $11.3 \%$, whereas glaciers in the Samnaungruppe (total area $0.082 \mathrm{~km}^{2}$ ) decreased in area by $59.8 \%$. In these regions there exist only a few very small glaciers, which generally show large variations in relation to the climatic conditions. This is observed not only in the investigated regions but also, for example, in Switzerland (Paul and others, 2004).

The comparison of the area-elevation distribution for both dates (Fig. 3) shows a maximum glacierized area at elevations of $2850-3000 \mathrm{~m}$ in 1969 . In the new inventory this maximum is shifted about $50 \mathrm{~m}$ (one elevation band) upward. The largest changes in glacier area, up to almost $8 \mathrm{~km}^{2}$, are observed in the altitude range $2700-2900 \mathrm{~m}$. The increase in glacier area within lower elevation bands results from the downwasting of extended glacier tongues and the consequential flattening of these glacier parts in low elevations. The mean glacier elevation in 1998 is $2914 \mathrm{~m}$, which represents a change of $0.4 \%$ since 1969 (2902 m). This rather small change of $12 \mathrm{~m}$ underlines that the loss in area affects all elevation bands, but with the emphasis on the lower elevations.

\section{Relative volume changes}

The total change in volume amounts to $4.9 \mathrm{~km}^{3}$ (ice and firn) for the time-span 1969-98. About a third of this volume was lost in the Ötztaler Alpen, which corresponds almost to the relative glacier area of this region. Also for the volume change the small glaciers show large variations.

Combining volume and area changes results in a mean elevation change of all glacier regions of $-8.7 \mathrm{~m}$ during the

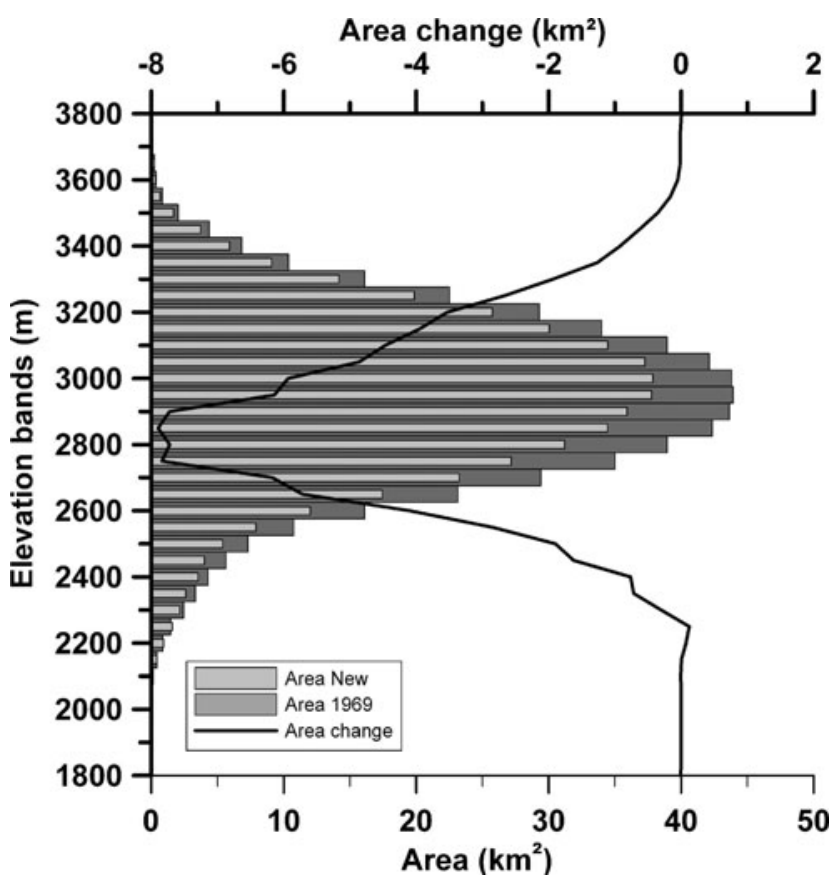

Fig. 3. Area-elevation distribution for 1969, the new inventory and the area change between the two inventories within $50 \mathrm{~m}$ elevation bands. The data were not temporally homogenized, because the small changes would not be visible.

29 years (change in ice volume divided by the total 1969 area). An analysis of the volume changes of individual glaciers (Fig. 4) indicates that some of the large glaciers lost considerably more ice than others. Major losses are observed for typical valley glaciers, with tongues reaching rather low elevations (e.g. Pasterzenkees, Gurglerferner, Obersulzbachkees), whereas glaciers with extensive firn areas (e.g. Gepatschferner) and high cirque glaciers show much smaller losses. The small glaciers, however, also show a variable reaction in terms of volume changes (Fig. 4). The maximum mean elevation change for the small glaciers $\left(<2 \mathrm{~km}^{2}\right.$ surface area) is $14.5 \mathrm{~m}$ for the entire period, or about $50 \mathrm{~cm} \mathrm{a}^{-1}$. The large valley glaciers, on the other hand, show values of up to $18.5 \mathrm{~m}$ in mean elevation change. This difference is due to the fact that the glacier tongues at low elevations showed highly negative specific balances between 1985 and 1998 (e.g. Hintereisferner: about $-6.6 \mathrm{~m} \mathrm{a}^{-1}$ of ice melt within the elevation bands between 2450 and $2700 \mathrm{~m}$ ). The small glaciers, however, which survive until today are usually situated in rather high elevations, at locations sheltered from solar radiation and/or in areas with very high accumulation rates.

The absolute maximum of volume change occurs in the 2800-2850 m elevation band (Fig. 5), about $100 \mathrm{~m}$ lower than the elevation band with the largest area. This demonstrates that very large areas are affected by net melting. Figure 5 also indicates, however, that glacier areas which usually are situated above the equilibrium line ( $\sim 3000-3200 \mathrm{~m}$ for the large glaciers) show a dynamic reaction to the volume reduction in the lower parts. In these lower elevation bands the volume reduction increases relative to the area extent, which is a consequence of the increasing net melt rates with lower altitudes. The relative area reduction, however, is not that pronounced at elevations below $2500 \mathrm{~m}$, due to the existence of flat glacier 


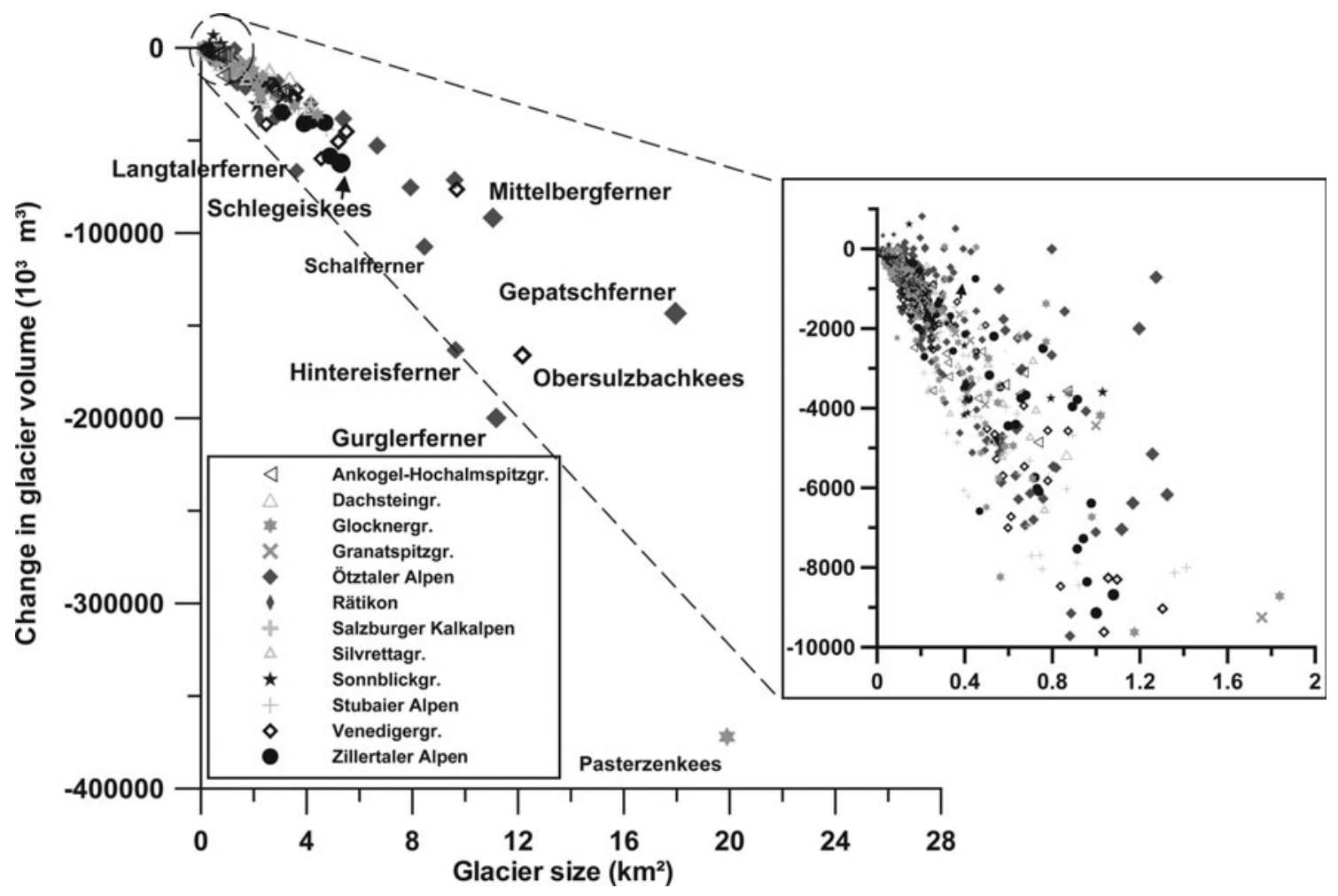

Fig. 4. Volume change vs glacier size (1969) for all glaciers. The relation for small glaciers up to $2 \mathrm{~km}^{2}$ is enlarged in the right panel.

tongues, as explained above. Only a few small glaciers survive in these regions, whereas the still thicker valley glacier tongues are strongly reduced in thickness but show only moderate area reductions.

The mean annual height difference, calculated from the volume change and glacier area within the single elevation bands, shows that within almost all elevation bands a loss of ice thickness occurs during the 29 years between the observations (Fig. 5). Only the topmost elevation band shows a very small increase. The vertical distribution of height change shows two distinct parts: a section with a moderate, almost linear, increase of height loss from the highest elevations down to about $2600 \mathrm{~m}$, followed by a strong acceleration in height loss from $2600 \mathrm{~m}$ to $2000 \mathrm{~m}$, reaching maximum values of $>2 \mathrm{~m} \mathrm{a}^{-1}$. Above $2600 \mathrm{~m}$ the values range between 0 and $0.5 \mathrm{ma}^{-1}$ in height loss. These observations represent an integral of the generally balanced years from 1970 until about 1985, strong negative net balance years during the 1990s, as well as the dynamic reaction to the strong thinning on the lower parts of the glaciers.

\section{An improved estimate for the glacier volume}

The existence of the two glacier inventories including elevation information for both epochs allows us to calculate volume estimates for the total glacier volume on a more reliable basis. A statistical investigation of mountain glaciers combined with a scaling analysis of the governing physics concluded that for an assemblage of glaciers the ice volume, $V$, is proportional to a power of the surface area, $A$, where the exponent for mountain glaciers is 1.36 (Chen and Ohmura, 1990; Bahr and others, 1997):

$$
V=f A^{1.36},
$$

with $f$ the constant of proportionality.
For the Austrian glacier inventories, two sets of glacier areas, $A_{1}, A_{2}$, and the volume differences, $\Delta V$, exist. For each glacier this can be written

$$
\Delta V=V_{2}-V_{1}=f A_{2}^{1.36}-f A_{1}^{1.36}=f\left(A_{2}^{1.36}-A_{1}^{1.36}\right) .
$$

From this equation the constant of proportionality, $f$, can be determined. In Figure 6, $f(=0.0041)$ is the slope of the linear fit, which has a squared regression coefficient of $R^{2}=0.88$. This constant $f$ can now be used to calculate ice volumes for the two different dates. So far only a rough estimate of the total ice volume has existed, assuming a mean ice thickness of $40 \mathrm{~m}$, and resulting in $21 \mathrm{~km}^{3}$ (Patzelt, 1978). Our method results in an ice volume of $22.8 \mathrm{~km}^{3}$ for 1969 and $17.7 \mathrm{~km}^{3}$ for 1998 . The volume loss of $5.1 \mathrm{~km}^{3}$ agrees well with the measured volume loss of $4.9 \mathrm{~km}^{3}$.

\section{CONCLUSIONS AND PERSPECTIVES}

With the new Austrian glacier inventory, an excellent basis exists for the investigation of recent glacier changes. Furthermore, this inventory will provide an important baseline for the future evolution of the glacier cover of the Austrian Alps. Important conclusions can already be drawn from the comparison of the two existing inventories, both provided in a fully digital form. The last three decades have shown a strong area reduction for almost all glacier regions in Austria. There is, however, a large variability in the degree of reduction. Strongly glacierized regions like the Ötztaler Alpen are dominated by larger glaciers, exceeding $5 \mathrm{~km}^{2}$ in area. For these regions the area change is uniform in the range $-17 \%$ to $-20 \%$. On the other hand, regions with little ice cover show a range of area change from $-60 \%$ to $+11 \%$, very much depending on special local conditions. The change of total glacier area has affected almost the entire altitude range. In the high-elevation 


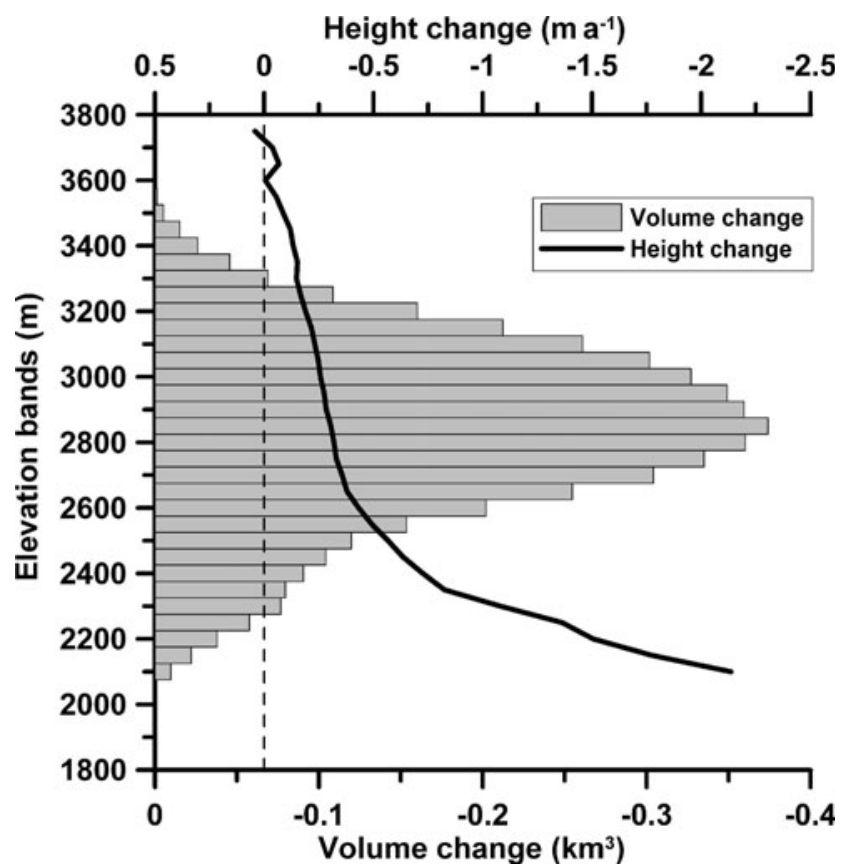

Fig. 5. Elevation distribution of the volume loss between the two inventories within $50 \mathrm{~m}$ elevation bands and the resulting change in height. The data were not temporally homogenized, because the small changes would not be visible.

regions, area and volume loss represent, at least for the larger glaciers, the dynamic reaction to the mass loss in lower elevations.

Volume changes are also observed within all elevation bands. The relative height change in different elevations (Fig. 5) resembles the shape of a vertical balance profile with a negative balance at all elevations. The loss is most pronounced below $2600 \mathrm{~m}$, whereas above this altitude only a moderate height change of $<0.5 \mathrm{~m} \mathrm{a}^{-1}$ is observed in general. In total, about $4.9 \mathrm{~km}^{3}$ of ice were lost during the 29 years between the inventories. However, most of this volume loss occurred between 1985 and 1998, during the last major phase of glacier recession. The rather accurate determination of volume change also enabled an improved calculation of the total ice volume of Austrian glaciers, of $22.78 \mathrm{~km}^{3}$ in 1969 . Therefore, the ice volume loss was about $22 \%$ of the total volume during three decades. Considering the fact that the major part of this volume was lost within about 13 years (1985-98, also comparing mass-balance series from glaciers in the Ötztal), a continuation of the recent negative mass-balance tendency would result in the loss of a large fraction of ice volume within the next 50 years. This is also in agreement with recent numerical model scenarios (Zemp and others, 2006). During the last two decades the mean equilibrium-line altitude (ELA) rose about $150 \mathrm{~m}$ to approximately $3100-3200 \mathrm{~m}$ (at least in the Ötztaler Alpen). Even for a moderate further rise in ELA, there will still be glaciers situated at elevations with positive balance conditions, but the total glacier area and volume would be strongly reduced.

\section{ACKNOWLEDGEMENTS}

The project is supported by the Austrian Academy of Sciences, Commission for Geophysical Research; Bund-

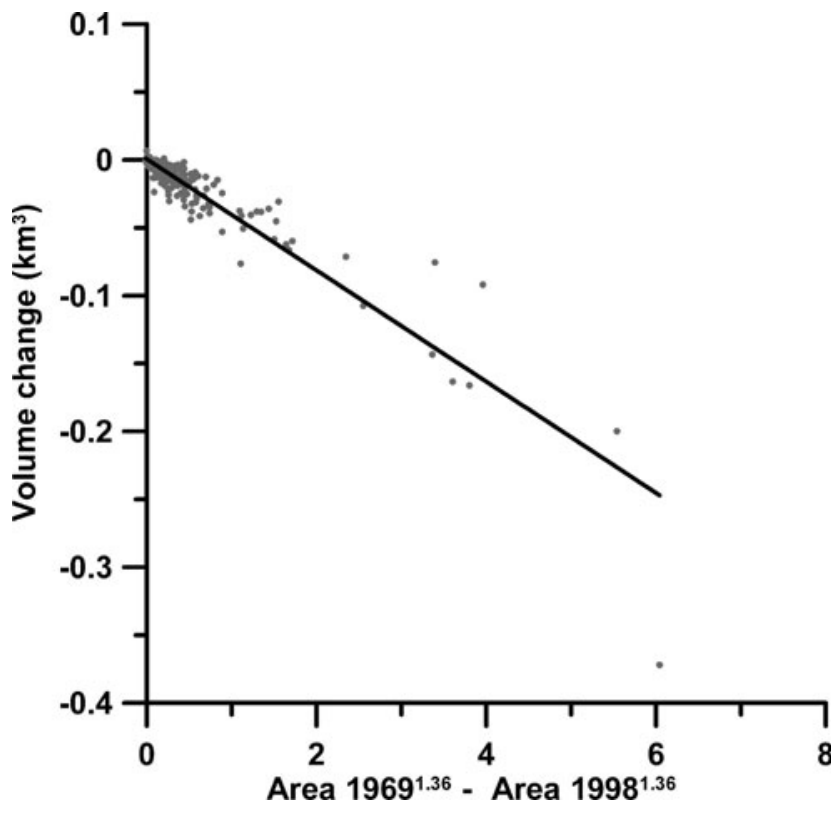

Fig. 6. Volume change vs area change $\mathrm{e}^{1.36}$. The straight line represents the linear fit, which shows a squared correlation coefficient of $R^{2}=0.88$.

Bundesländerkooperation; Hydrographisches Zentralbüro; Hydrographischer Dienst Tirol; Österreichischer Alpenverein; and Tiroler Wissenschaftsfonds (GZ: UNI-0404/ 304). Sincere thanks also to Dipl. Ing. J. Zistler for his survey of Eiskargletscher, Karnische Alpen, and the generation of the associated digital elevation contour map. R. Wurlander is gratefully acknowledged for allowing free use of the GLEDIFF software to analyze glacier volume changes.

\section{REFERENCES}

Bahr, D.B., M.F. Meier and S.D. Peckham. 1997. The physical basis of glacier volume-area scaling. J. Geophys. Res., 102(B9), 20,355-20,362.

Chen, J. and A. Ohmura. 1990. Estimation of Alpine glacier water resources and their change since the 1870s. IAHS Publ. 193 (Symposium at Lausanne 1990 - Hydrology in Mountainous Regions I), 127-135.

Church, J.A. and 7 others. 2001. Changes in sea level. In Houghton, J.T. and 7 others, eds. Climate change 2001: the scientific basis. Contribution of Working Group I to the Third Assessment Report of the Intergovernmental Panel on Climate Change. Cambridge, etc., Cambridge University Press, 639-693.

Dyurgerov, M. 2003. Mountain and subpolar glaciers show an increase in sensitivity to climate warming and intensification of the water cycle. J. Hydrol., 282(1-4), 164-176.

Eder, K., R. Würländer and H Rentsch. 2000. Digital photogrammetry for the new glacier inventory of Austria. Int. Arch. Photogramm. Remote Sens., 33(B4/1), 254-261.

Finsterwalder, R. 1953. Die zahlenmäßige Erfassung des Gletscherrückgangs an Ostalpengletschern. Z. Gletscherkd. Glazialgeol., 2, 189-293.

Groß, G. 1987. Der Flächenverlust der Gletscher in Österreich 1850-1920-1969. Z. Gletscherkd. Glazialgeol., 23(2), 131-141.

Hoinkes, H. and R. Steinacker. 1975. Zur Parametrisierung der Beziehung Klima-Gletscher. Riv. Ital. Geofis. Sci. Aff., 1, 97-104. 
Lang, H. 1968. Relations between glacier runoff and meteorological factors observed on and outside the glacier. IASH Publ. 79 (General Assembly of Bern 1967 - Snow and Ice), 429-439.

Patzelt, G. 1978. Der Österreichische Gletscherkataster. In Almanach '78 der Österreichischen Forschung. Vienna, Verband der wissenschaftlichen Gesellschaften Österreichs, 129-133.

Patzelt, G. 1980. The Austrian glacier inventory: status and first results. IAHS Publ. 126 (Riederalp Workshop 1978 - World Glacier Inventory), 181-183.

Patzelt, G. 1993. Die Gletscher der Österreichischen Alpen 1989/ 1990 - Sammelbericht über die Gletschermessungen des Österreichischen Alpenvereins im Jahre 1990. Z. Gletscherkd. Glazialgeol., 29(2), 179-190.

Paul, F., A. Kääb, M. Maisch, T. Kellenberger and W. Haeberli. 2002. The new remote-sensing-derived Swiss glacier inventory. I. Methods. Ann. Glaciol., 34, 355-361.

Paul, F., A. Kääb, M. Maisch, T. Kellenberger and W. Haeberli. 2004. Rapid disintegration of Alpine glaciers observed with satellite data. Geophys. Res. Lett., 31(21), L21402. (10.1029/ 2004GL020816.)

Reinhardt, W. and H. Rentsch. 1986. Determination of changes in volume and elevation of glaciers using digital elevation models for the Vernagtferner, Ötztal Alps, Austria. Ann. Glaciol., 8, 151-155.
Rentsch, H., W. Welsch, C. Heipke and M.M. Miller. 1990. Digital terrain models as a tool for glacier studies. J. Glaciol., 36(124), 273-278.

Schicker, I. 2006. Changes in area of Stubai glaciers analysed by means of satellite data for the GLIMS project. (Diploma thesis, University of Innsbruck.)

UNESCO. 1970. Perennial ice and snow masses: a guide for compilation and assemblage of data for a world inventory. UNESCO/IASH Tech. Pap. Hydrol. 1.

Würländer, R. and K. Eder. 1998. Leistungsfähigkeit aktueller Photogrammetrischer Auswertemethoden zum Aufbau eines digitalen Gletscherkatasters. Z. Gletscherkd. Glazialgeol., 34(2), 167-185.

Würländer, R. and M. Kuhn. 2000. Zur Erstellung und Anwendung der Produkte des neuen Österreichischen Gletscherkatasters. Salzburger Geogr. Arbeit., 36, 57-67.

Würländer, R., L.N. Braun and H. Escher-Vetter. 1999. Einsatz von digitalen Geländedaten zur Umweltanalyse mit Beispielen aus dem Hochgebirge. In Heipke, C. and H. Mayer, eds. Festschrift für Prof. Dr.-Ing. Heinrich Ebner zum 60. Geburtstag. Munich, Technische Universität München. Lehrstuhl für Photogrammetrie und Fernerkundung, 335-346.

Zemp, M., W. Haeberli, M. Hoelzle and F. Paul. 2006. Alpine glaciers to disappear within decades? Geophys. Res. Lett., 33(13), L13504. (10.1029/2006GL026319.) 